\title{
VALIDASI METODE ANALISIS POLISIKLIK AROMATIK HIDROKARBON (PAH) DALAM SEDIMEN DI SEKITAR PANTAI MAKASSAR
}

\section{VALIDATION OF ANALYSIS METHOD OF POLYCICLIC AROMATIC HIDROCARBON (PAH)IN SEDIMENTS FROM MACASSAR COAST}

\author{
Muhammad Syahrir $^{1)}{ }^{2)}$, Nurul Hidayat Aprilita ${ }^{3)}$, dan Nuryono ${ }^{4)}$ \\ ${ }^{1}$ Doctoral Candidat Programme of Chemistry, Gadjah Mada University \\ ${ }^{2)}$ Chemistry Departement Faculty of Science Makassar State University \\ 3), 4) Chemistry Departement, Faculty of Science Gadjah Mada University \\ Email : syahrirun@ymail.com
}

Diterima: 12 Februari 2015, Revisi: 12 Maret 2015, Disetujui: 06 April 2015

\begin{abstract}
ABSTRAK
Telah dilakukan validasi metode analisis PAH dalam sedimen laut Pantai Makassar dengan kromatografi gas (GC-FID). Validasi metode ini meliputi limit deteksi (LoD), limit kuantifikasi (LoQ), linearitas dan rentang linear. Hasil validasi metode terhadap 7 jenis PAH (Naphtalene, Acenaphtene, Penanthrene, Fluoranthene, Pyrene, Benzo (a) Anthracene dan Perylene) mempunyai rentang linear: 0,5 - 20 ppm dengan rata-rata linearitas mendekati nilai 1 . LoD secara berturutturut untuk Naphtalene; Acenaphthene; Penanthrene; Fluoranthene; Pyrene; Benzo (a) Anthracene; dan Perylene adalah 3,541; 0,208; 1,$736 ; 1,737 ; 1,738 ; 12,124$ dan 2,128 ppm. LoQ secara berturut-turut untuk Naphtalene; Acenaphthene; Penanthrene; Fluoranthene; Pyrene; Benzo(a) Anthracene dan Perylene adalah 11,803; 0,695; 5,786; 5,786; 5,788; 5,794; 7,0796 dan 7,092 ppm. Limit deteksi (LoD), limit kuantifikasi (LoQ), linearitas dan rentang linear tersebut dapat digunakan dalam menentukan konsentrasi PAH dalam sampel sedimen.
\end{abstract}

Kata kunci: Validasi Metode, Konsentrasi, PAH, Sedimen

\section{ABSTRACT}

Validation of analysis method of PAH have been done in marine sediment of Macassar Coast by Gas Chromatography (GC-FID). Validation of method include: limit of detection (LoD), limit of quantification (LoQ) and linearity range. The results of validation method of 7 types PAHs (Naphtalene, Acenaphtene, Penanthrene, Fluoranthene, Pyrene, Benzo (a) Anthracene and perylene) give a linearity range between 0.5 to $20 \mathrm{ppm}$ with an average linearity approaches a value of 1. LoD for Naphtalene; Acenaphthene; Penanthrene; Fluoranthene; Pyrene; Benzo (a) Anthracene; and Perylene are $3.541 ; 0.208 ; 1,736 ; 1.737 ; 1,738$; 12.124; and 2,128 ppm, respectively. LoQ for Naphtalene; Acenaphthene; Penanthrene; Fluoranthene; Pyrene; Benzo (a) Anthracene; and Perylene are 11,803; 0.695; 5.786; 5.786; 5.788; 5.794; 7.0796 and $7.092 \mathrm{ppm}$, respectively. Limit of detection (LoD), limit of quantification (LoQ), linearity and linear range can be used to determine the concentration of PAH in sediment samples.

Keywords: Validation Method, Concentration, PAH, Sediments

\section{PENDAHULUAN}

Indonesia terdiri atas 17.508 pulau dengan panjang garis pantainya lebih daripada $81.000 \mathrm{~km}$ dan $70 \%$ dari jumlah penduduknya hidup di kawasan Pesisir ${ }^{(1-2)}$. Keadaan ini sangat menguntungkan mengingat potensi laut yang sangat besar, baik sebagai sumber alam yang melimpah maupun sebagai sarana perhubungan, perdagangan dan pariwisata. Negara-negara yang berbatasan di Selat Malaka telah berhasil menyepakati ketentuan-ketentuan dalam mengatasi masalah lingkungan hidup, namun upaya penegakan hukum terhadap penanganan masalah lingkungan hidup di Selat Malaka belum terlaksana baik akibat koordinasi antar instansi dalam penegakan hukum belum terpadu ${ }^{(3)}$. 
PAH perlu selalu dipantau keberadaannya karena dapat menyebabkan mutasi genetik dan menimbulkan penyakit kanker. PAH termasuk golongan zat kimia yang bersifat genotoksik dan memberikan efek dapat membentuk ikatan kovalen dengan basa dari DNA. PAH memiliki gugus elektrofil yang akan membentuk ikatan kovalen dengan gugus nukleofilik seperti asam amino, sulfohidril dan gugus hidroksil pada molekul lain ${ }^{(4)}$.

Analisis PAH masih sangat jarang dilakukan di Indonesia sampai saat ini, padahal senyawa PAH sangat bersifat toksik dan sangat mempengaruhi mutu kualitas lingkungan yang berakibat fatal bagi manusia. Penggunaan GC-FID dalam analisis PAH dalam sedimenmemiliki tingkat selektivitas dan keakuratan lebih tinggi dibandingkan dengan HPLC dengan mengacu prosedur standar EPA (Environmental Protection Agency) $^{(5)}$.

Preparasi sampel dengan menggunakan ekstraksi soxhlet memiliki banyak kelemahan di antaranya, kemungkinan timbulnya emulsi, banyaknya jumlah pelarut organik yang digunakan, menghasilkan limbah pelarut organik dalam jumlah besar, proses ekstraksinya membutuhkan waktu lama, dan tidak dapat dilakukan secara otomatis. Metode ini cukup praktis bagi analis karena tidak terlalu banyak berinteraksi langsung dengan bahan kimia yang digunakan serta alat umumnya tersedia pada semua Laboratorium Kimia di Indonesia, sehingga memungkinkan melakukan analisis secara akurat ketika suatu lingkungan terindikasi adanya PAH. Penelitian yang berkaitan dengan ini maupun berbagai metode yang telah dikembangkan yaitu metode EPA 610, EPA 8270 C, Golledge \& Herzfelder (6-8), dalam mempreparasi sampel sedimen sebelum ekstraksi umumnya memakai sedimen basah tanpa dikeringkan yang memerlukan waktu 1 x 24 jam dengan menjaga kondisinya dibawah $4{ }^{\circ} \mathrm{C}$ ditransfer dari lingkungan ke laboratorium serta disimpan dalam freeze dried atau lemari pendingin. Melihat dari kekurangan dari metode ini, maka diperlukan suatu metode yang tepat untuk memodifikasi metode telah ada.

Modifikasi metode ini adalah menggunakan sampel sedimen kering pada suhu kamar dan sampel yang sedikit sehingga mempermudah dalam analisis. Kinerja metode analisis dengan cara ini dapat dipastikan dan dilakukan langkah validasi metode. Validasi metode adalah proses yang menunjukkan atau membuktikan karakteristik kinerja suatu metode analisis dapat diterima atau tidak ${ }^{(9)}$.

\section{BAHAN DAN METODE}

\section{Bahan}

Bahan kimia yang digunakan antara lain: Standar PAH (Aldrich, Jerman) meliputi: Napthalene, Pyrene, Fluoranthene, Phenanthrene, Acenaphtene, Perylene, Benzo (a) Pyrene. Bahan kimia lainnya: natrium sulfat anhidrat, silika gel 70 - 240 mesh, alumina, berkualitas p.a. (E.Merck, USA) sedangkan gas helium, hidrogen, dan nitrogen buatan (Aneka Gas, Indonesia). Pelarut n-heksana, diklorometana yang mempunyai kualitas p.a. (E.Merck, USA). Air yang digunakan adalah aquabides (Pharmaceutical Lab, Indonesia) dan air suling produksi laboratorium (LPPT UGM, Indonesia).

Alat-alat yang digunakan dalam penelitian ini adalah alat gelas (Pyrex, USA), rotary evaporator Buchii $R$ II (Buchii, Indonesia), pompa vakum (Hitachi, Ltd., Jepang), pengayak $1.00 \mathrm{~mm}$ No.18 (Fisher Scientific Company, USA), neraca analitik Al.204 (Mettler Toledo, Swiss), Oven model 501 (Fisher, USA), termometer $\left(100{ }^{\circ} \mathrm{C}\right)$ (Hanna HI 8314, USA), hand refraktometer (Kenko, Indonesia), Van Veen Grab (Stainless Steel, Indonesia), GPS (Global Positioning System) (Garmin 
76 CSX, Indonesia) dan kromatografi gas detektor FID (Shimadzu QP 2010, Jepang).

\section{Metode}

Sampel sedimen diambil dengan menggunakan alat Van Veen Grab di sekitar Pantai Pulau Lae-lae Makassar, Sulawesi Selatan pada titik koordinat $\mathrm{S} 05^{\circ}$ 08. 131' dan E $119^{\circ} 23.416^{\prime}$, kemudian dibungkus dengan aluminium foil serta dibawa ke laboratorium pada suhu kamar.

Sampel sedimen sebanyak 10 gram diekstraksi selama 18 jam dengan pelarut diklorometana dan n-heksana $(50: 50=\mathrm{v} / \mathrm{v}$ $=1: 1$ ) pada suhu $45{ }^{\circ} \mathrm{C}$ (Golledge, $2004 \&$ Elias et.al, 2007). Ekstrak yang dihasilkan diuapkan pelarutnya dengan rotavapor Buchii sehingga diperoleh ekstrak bahan organik (EBO) pada suhu $45{ }^{\circ} \mathrm{C}$ (EPA Method 8270). Pemisahan zat organik lainnya yang terbawa selama ekstraksi dilakukan clean-up. Clean-up menggunakan alumina yang bersifat basa, dan alumina yang akan digunakan diproses dulu sebagai berikut: \pm 200 gram alumina diekstraksi dengan diklorometana dalam soxhlet selama kurang lebih 16 jam, kemudian dipanaskan dalam oven dengan suhu $200{ }^{\circ} \mathrm{C}$ selama 8 jam, selanjutnya dinonaktifkan dengan menambahkan akuabides $(9-10 \%)$. Hasil destilat dari clean-up dilanjutkan dengan proses pemisahan yaitu menggunakan silika gel alumina (1:1) untuk mendapatkan dua fraksi yaitu fraksi alifatik dan aromatik. Fraksi aromatik mengandung PAH dianalisis dengan kromatografi GC-FID dengan metode standar eksternal dengan berbagai variasi kondisi operasional kromatografi gas dan diperoleh kondisi optimal (Tabel 1).

Tabel 1. Hasil optimasi kromatografi untuk pemisahan $\mathrm{PAH}$

\begin{tabular}{ll}
\hline \multicolumn{1}{c}{ Jenis } & \multicolumn{1}{c}{ Keterangan } \\
\hline Kolom & CP-Sil-8-CB \\
Fase gerak & $\begin{array}{l}\text { Gas nitrogen dengan kecepatan alir 30 } \\
\mathrm{ml} / \mathrm{mnt}\end{array}$ \\
Detektor & FID dengan suhu $310{ }^{\circ} \mathrm{C}$ \\
Temp. Program & $310-340{ }^{\circ} \mathrm{C}$ \\
\hline
\end{tabular}

Penentuan parameter kinerja metode (validasi metode) analisis menggunakan sampel sedimen laut yang paling tidak terkontaminasi sebagai blangko PAH.

Kadar PAH dalam sedimen dihitung menggunakan rumus ${ }^{(9)}$ berikut:

$$
\mathrm{C}_{\mathrm{x}}=\frac{\mathrm{C} \times \mathrm{Vxfp}}{\mathrm{BS}}
$$

Keterangan:

$\mathrm{C}_{\mathrm{x}}=$ konsentrasi PAH (ppm)

$\mathrm{C}=$ konsentrasi sampel yang diperoleh dari persamaan regresi linear (ppm)

$\mathrm{V}=$ volume larutan sampel $(\mathrm{ml})$

$\mathrm{Fp}=$ Faktor Pengenceran

BS $=$ Berat Sampel $(\mathrm{g})$

\section{HASIL DAN PEMBAHASAN}

Senyawa PAH standar masingmasing telah dilakukan analisis dengan menggunakan program optimasi kromatografi GC-FID di atas.

Data yang diperoleh berupa waktu retensi masing-masing senyawa seperti pada Tabel 2 .

Tabel 2. Data waktu retensi masing-masing senyawa $\mathrm{PAH}$

\begin{tabular}{lc}
\hline \multicolumn{1}{c}{ PAH } & $\begin{array}{c}\text { Waktu retensi } \\
\text { (menit) }\end{array}$ \\
\hline Naphtalene & $4,83 \pm 0,01$ \\
Acenaphtene & $6,73 \pm 0,00$ \\
Penanthrene & $9,56 \pm 0,00$ \\
Fluoranthene & $12,54 \pm 0,01$ \\
Pyrene & $13,15 \pm 0,00$ \\
Benzo(a)antracene & $16,86 \pm 0,00$ \\
Perylene & $24,05 \pm 0,04$ \\
\hline
\end{tabular}

Jumlah pelat teoritis $\left(\mathrm{N}_{\text {req }}\right)$ untuk semua jenis PAH pada Tabel 3 di bawah ini mempunyai nilai lebih besar dari 7000 sehingga memenuhi syarat dan diharapkan terjadinya kesetimbangan analit dalam fase diam dan fase gerak dapat memungkinkan tercapainya pemisahan PAH secara sempurna. Hal tersebut didukung dengan faktor kapasitas pada umumnya memenuhi syarat dengan nilai k' lebih besar dari 1 (satu) kecuali pada Naphtalena. 
Tabel 3. Daftar faktor kapasitas dan jumlah pelat teoritis dari masing-masing $\mathrm{PAH}$ dari hasil analisis GC-FID kolom CP-Sil-8-CB

\begin{tabular}{lrrr}
\hline Jenis PAH & \multicolumn{1}{c}{$\begin{array}{c}\text { tr } \\
\text { (menit) }\end{array}$} & $\begin{array}{c}\text { Jumlah plat } \\
\text { teoritis }\end{array}$ & $\begin{array}{c}\text { Faktor } \\
\text { kapasitas }\end{array}$ \\
\hline Naphtalene & 6,944 & 14.400 & 0,799 \\
Acenaphtene & 6,808 & 67,600 & 1,690 \\
Fluoranthene & 12,694 & 47,524 & 1,754 \\
Pyrene & 13,329 & 40535,111 & 3,889 \\
Benzo (a) & 17,094 & 47233,78 & 4,195 \\
Antracene & 24,459 & 16965,225 & 6,240 \\
Perylene &
\end{tabular}

Keterangan: tr adalah waktu retensi dari $P A H, t m$ adalah waktu retensi dari fase gerak 3,888 menit

Waktu retensi untuk semua PAH berbeda jauh bahkan dalam campuran tetap memperlihatkan suatu pemisahan yang baik antara kedua puncak yang berdekatan waktu retensinya. Hal tersebut dapat dilihat pada Gambar 1.

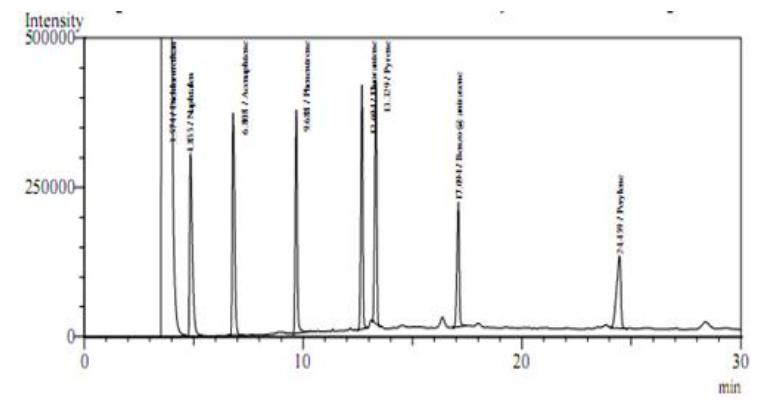

Gambar 1. Kromatogram standar PAH campuran 1000 ppm: Naphtalene, Acenaphtene, Penanthrene, Fluoranthene, Pyrene, Benzo (a) Antracene dan Perylene

Hasil perhitungan di atas menunjukkan bahwa memenuhi syarat nilai k' nya (faktor kapasitas) kecuali pada Naphtalene. Jumlah Pelat Teoritis juga memenuhi syarat $\mathrm{N}_{\text {req }}$ lebih dari 7000 sehingga diharapkan frekuensi terjadinya kesetimbangan analit dalam fase diam dan fase gerak dapat memungkinkan tercapainya pemisahan PAH secara sempurna.

Linearitas metode analisis PAH dalam sedimen dengan GC-FID ditentukan dengan cara membuat kurva hubungan antara luas area pada sumbu y dan konsentrasi standar pada sumbu $\mathrm{x}$. Konsentrasi yang digunakan berkisar antara
0.5 - $20 \mathrm{ppm}$. Pengujian parameter ini dilakukan seperti dalam Tabel 4 berikut yang menyajikan persamaan regresi linear dari masing-masing kurva standar. Linearitas dinyatakan dengan koefisien korelasi (r). Berdasarkan hasil pengujian, diperoleh koefisien korelasi berkisar antara 0,970 - 0,998, dan untuk kurva standard rata-rata sebesar 0,997. Nilai koefisien korelasi yang tinggi dan mendekati nilai 1 menunjukkan hasil yang baik dan menunjukkan adanya hubungan proporsional antara sinyal detektor GC-FID dengan konsentrasi PAH sampel yang terukur.

Tabel 4. Nilai Regresi (r) dan Persamaan regresi linear standar

\begin{tabular}{llcc}
\hline \multicolumn{1}{c}{ PAH } & \multicolumn{1}{c}{$\begin{array}{c}\text { Persamaan } \\
\text { Regresi Linear }\end{array}$} & $\begin{array}{c}\text { Rentang } \\
\text { Linear }\end{array}$ & R \\
\hline Naphtalene & $\mathrm{y}=7134 \mathrm{x}+470,3$ & $0,5-20$ & 0,992 \\
Acenaphtene & $\mathrm{y}=7593 \mathrm{x}+4502$ & $0,5-20$ & 0,991 \\
Penanthrene & $\mathrm{y}=9816 \mathrm{x}+4104$ & $0,5-20$ & 0,997 \\
Fluoranthene & $\mathrm{y}=9522 \mathrm{x}-701,6$ & $0,5-20$ & 0,993 \\
Pyrene & $\mathrm{y}=8373 \mathrm{x}-4298$ & $0,5-20$ & 0,996 \\
Benzo (a) & $\mathrm{y}=11871 \mathrm{x}+2027$ & $0,5-20$ & 0,999 \\
Antracene & $\mathrm{y}=3594 \mathrm{x}-991,9$ & $0,5-20$ & 0,997 \\
Perylene & & & \\
\hline
\end{tabular}

\section{Penentuan Limit Deteksi dan Limit Kuantifikasi}

Limit deteksi (LoD) dan limit kuantifikasi (LoQ) ditentukan dari persamaan regresi linear kurva standar ratarata hasil penentuan linearitas. Limit deteksi analisis Acenaphtene dalam sampel sedimen dengan GC-FID didapatkan sebesar 0,208 ppm. Nilai ini menunjukkan bahwa sinyal antara sampel dan blangko dapat dibedakan pada konsentrasi terendah 0,208 ppm. Metode tidak dapat membedakan sinyal antara blangko dan sampel pada konsentrasi di bawah nilai ini,begitu juga pada senyawa PAH target lainnya: Acenaphtene, Penantrene, Fluoranthene, Pyrene, Benzo (a) Antracene dan Perylene sebagaimana digambarkan pada Tabel 5. 
Limit kuantifikasi ditentukan untuk mengetahui konsentrasi terendah yang dapat ditentukan oleh suatu metode pada tingkat ketelitian dan ketepatan yang baik. Nilai limit kuantifikasi PAH berdasarkan hasil penelitian adalah terdapat pada Tabel 5. Konsentrasi PAH yang terukur di bawah nilai ini memberikan ketelitian dan ketepatan yang kurang baik.

Tabel 5. Perhitungan Nilai LoD dan LoQ dari PAH standar tunggal

\begin{tabular}{lcc}
\hline \multicolumn{1}{c}{ PAH } & $\begin{array}{c}\text { LoD } \\
\text { (ppm) }\end{array}$ & $\begin{array}{c}\text { LoQ } \\
\text { (ppm) }\end{array}$ \\
\hline Naphtalene & 1,094 & 3,647 \\
Acenaphtene & 0,208 & 0,695 \\
Penanthrene & 1,246 & 5,786 \\
Fluoranthene & 1,744 & 5,814 \\
Pyrene & 1,738 & 5,794 \\
Benzo (a) Antracene & 2,124 & 7,079 \\
Perylene & 2,128 & 7,090 \\
\hline
\end{tabular}

\section{KESIMPULAN}

Pengujian parameter validasi metode menunjukkan bahwa metode validasi penentuan PAH dalam sampel sedimen kering pada suhu kamar dengan menggunakan kurva kalibrasi PAH standar tunggal dalam sedimen Pantai Makassar dan alat instrumen GC-FID mempunyai kinerja yang baik dan tervalidasi.

Validasi metode menunjukkan bahwa 7 jenis PAH (Naphtalene, Acenaphtene, Penanthrene, Fluoranthene, Pyrene, Benzo (a) Antracene dan Perylene mempunyai hasil rentang linear pada umumnya dari $0,5-20 \mathrm{ppm}$ dengan rata-rata nilai regresi linear mendekati nilai 1. Limit deteksi (LoD) secara berturut-turut untuk Naphtalene; Acenaphtene; Penanthrene; Fluoranthene; Pyrene; Benzo (a) Antracene; dan Perylene adalah $(1,094 ; 0,208 ; 1,246$; 1,$744 ; 1,738 ; 2,124$; dan 2,128) ppm. Limit kuantifikasi (LoQ) secara berturut-turut untuk Naphtalene; Acenaphtene; Penanthrene; Fluoranthene; Pyrene; Benzo (a) Antracene; dan Perylene adalah $(3,647$; 0,$695 ; 5,786 ; 5,814 ; 5,794 ; 7,08$ dan 7,092) ppm.

\section{UCAPAN TERIMA KASIH}

Kami mengucapkan banyak terima kasih atas selesainya penelitian ini kepada Pihak Laboratorium LPPT UGM khususnya Bapak Bambang Sutriyanto selaku analis di Laboratorium GC-FID yang senantiasa memberikan sumbangsih baik moril maupun material sehingga penelitian kami dapat berjalan dengan baik dan lancar.

\section{DAFTAR PUSTAKA}

1. Nontji, A. Laut Nusantara. Penerbit Djambatan. Jakarta, 1997, Cetakan Kedua.

2. Nontji, A. Coral Reefs of Indonesia: Past, Present and Future. Proc. Lok. Pengelolaan \& Iptek Terumbu Karang Indonesia. Jakarta, 1999.

3. Suhaidi. Pengelolaan Keamanan Selat Malaka Secara Terpadu.Badan Pengkajian dan Pengembangan Kebijakan Departemen Luar Negeri RI.Journal of Foreign Affairs (2005).

4. Lukitaningsih,E., Sudarmanto,B.S.A., Primadesa, L. Bioakumulasi PAH dalam Panaceus merquensis dan Calappa flammea di Perairan laut Selatan Jogjakarta. Majalah Farmasi Indonesia, Yogyakarta. 15(3), 110-11 (2004).

5. Lukitaningsih, E. Tesis Pascasarjana. Jurusan Farmasi FMIPA UGM. Universitas Gadjah Mada, Yogyakarta (1999).

6. EPA 8270 C. Semivolatile Organic Compounds by Gas Chromatography / Mass Spectrometry (GC-MS). 1996, Revisi 3.

7. Golledge,W.R.\& Herzfelder,E.R. Method for the Determination of extractable Petroleum Hydrocarbons $(E P H)$. Department of Environmental Protection. Bureau, 2004, Revision 1.1.

8. Golledge,W.R., Herzfelder,E.R. Method for the Determination of Extractable 
Petroleum Hydrocarbons (EPH). Department of Environmental Protection. Bureau, 2009, Revision 2.1.

9. Nurkaromah, A., Permanasari,A., Zackiyah. Validasi Metode Analitik Kalsium dalam Tanah dengan AAS.Jurnal Sains dan Teknologi Kimia, UPI, Bandung (2011).

10. Anonim. Determination of PAHs in Ambient Using Gas Chromatography/Mass Spectrometry $(G C-M S)$. Second Edition. U.S. Environmental Protection Agency Cincinnati, 1999, OH 452686.

11. Damas,E.Y.C., $\quad$ Medina,M.O.C., Clemente,A.C.N., Diaz,M.A.D. Validation of Analytical Methodology for the Quantitative analysis of Petroleum Hydrocarbon in Marine Sediment Samples.Quim NovaVol.32.,No.4, 855-860 (2009).

12. Emanuel Coelho, et.al. Analysis of PAH by SPME-GC-FID in Environmental and Tap Waters, Jurnal BrazChem., Vol. 19. No.6. 1084-1097 (2008).

13. IARC.,1983. IARC Monographs on the Evaluation of the Carcinogenicity of Chemicals to Humans, Polycuclear Aromatic Compounds, Part 1: Chemical, Environmental and Experimental Data, Lyon, 1983, Vol.32.

14. IARC.,1998. IARC Monographs on the Evaluation of Carcinogenic Risks to Humans, Polynuclear Aromatic Compounds, Part 1: Chemical, Environmental and Experimental Data. Lyon, 1998, Vol.32.

15. IARC. IARC Monographs on the Evaluation of Carcinogenic Risks to Humans. Some Non-heterocyclic Polycyclic Aromatic Hydrocarbons and Some Related Exposures. IARC Working Group on the Evaluation of Carcinogenic Risks to Humans. Lyon, 2010, Vol.92.
16. Jose Ricardo Lima Bispo,et.al. Method Validation for SPE Applied to Determination of PAH in Petroliferous Industry Effluent Water. American Journal of Analytical Chemistry, Vol.2, 971-978 (2011)

17. Rohman,Abd., Harsojo,Raharjo,T.J., Sismindari, Tryana,K., Astuti, K. Analisis Makanan dan Lingkungan Secara Fisika-Kimia. Pustaka Pelajar. Yogyakarta, 2012.

18. Ru Xiao, Du Xiaoming, He Xiaozhen, Yuejin,Z., Yi Zhihua, Li Fashen. Vertical Distribution of Polycyclic Aromatic Hydrocarbons (PAHs) in Hunpu Wastewater-irrigated Area in Northeast China under Different Land Use Patterns.Environ Monit Assess.Springer Science + Business Media B.V., (2008).

19. Hadi, A. Pemahaman dan Penerapan ISO/IEC/17025:2005. Persyaratan Umum Kompetensi Loboratorium Pengujian dan Laboratorium Kalibrasi. PT. Gramedia Pustaka Utama, Jakarta, 2007.

20. Harmita. Petunjuk Pelaksanaan Validasi Metode dan Cara Perhitungannya. Majalah Ilmu Kefarmasian, Bandung, Vol.I.No.3, 117-135 (2004). 